\title{
Biological investigations of different leaf extracts of Litsea liyuyingi (Family-Lauraceae)
}

\author{
Farhina Rahman Laboni ${ }^{1}$, Salman Mahmud ${ }^{1}$, Samira Karim ${ }^{1}$, Sajan Das ${ }^{2}$ and \\ Mohammad Shahriar ${ }^{2 *}$ \\ ${ }^{I}$ Department of Pharmacy, World University of Bangladesh, Dhaka-1205, Bangladesh. \\ ${ }^{2}$ Department of Pharmacy, University of Asia Pacific, Dhaka-1215,Bangladesh.
}

\begin{abstract}
In this present study, the leaf extracts of Litsea liyuyingi, were subjected to evaluate the phytochemical screenings, thrombolytic, membrane stabilizing, antioxidant, antimicrobial, cytotoxic, antinociceptive, anti-diarrheal and hypoglycemic activity. In phytochemical screening the presence of flavonoids, saponins, alkaloids, phenols and tannins were detected in the plant leaf extract. Methanol (43.55\%) extract and its pet-ether fraction (42.11\%) showed good thrombolytic effects and good membrane stabilizing effects were observed by carbon tetrachloride and aqueous soluble fractions respectively. Two different assays were performed to evaluate antioxidant activity. The presence of phenolic contents and free radical scavenging activity was remarkable in the methanol extract and its pet-ether fraction. Crude methanol extract and other fractions showed effects against gram positive and gram negative bacteria as well as demonstrated effects to A. Salina with $L C_{50}$ values ranging from 1.04 to $9.41 \mu \mathrm{g} / \mathrm{ml}$ and $L C_{90}$ values ranging from 30.20 to $82.14 \mu \mathrm{g} / \mathrm{ml}$ as compared to contro. Statistically significant $\left({ }^{* *} p<0.01 ; * * * 0<0.001\right)$ result was found in case of in vivo antinociceptive activity test for the $400 \mathrm{mg} / \mathrm{kg}$ methanol extract when compared to control. The crude methanol extracts of leaves also possessed significant anti-diarrheal $\left({ }^{*} p<0.05\right)$ and hypoglycemic $(* * p<0.01)$ activity at $400 \mathrm{mg} / \mathrm{kg}$.
\end{abstract}

Keywords: Litsea liyuyingi, phytochemical screening, in vitro thrombolytic, membrane stabilizing, antioxidant, antibacterial, cytotoxic, in vivo anti-nociceptive, anti-diarrheal and hypoglycemic activity

\section{Introduction}

Herbal products are often perceived as safe because they are "natural" [1]. The term 'crude drugs of natural or biological origin' is used by pharmacists and pharmacologists to describe whole plants or parts of plants which have medicinal properties [2] because of having enormous versatility in synthesizing complex materials. Secondary metabolites or phytochemicals are naturally, occurring and biologically active plant compounds that have potential disease inhibiting capabilities as well as believed phytochemicals may be effective in combating or preventing disease due to their antioxidant effect [3]. Antioxidants are vital substances that protect other molecules (in vivo) from oxidation when they are exposed to free radicals and reactive oxygen species which have been implicated in the etiology of many diseases and in food deterioration and spoilage [4-5].

Litsea liyuyingi is an evergreen shrubs or small trees grows up to 3 meter tall having leaves opposite or alternate on same tree with hairy like branchlets; leaf blade elliptic, oblong, lanceolate, oblong-lanceolate, or elliptic-lanceolate, yellow brown or ferruginous tomentose or gray-yellow appressed pubescent abaxially, base cuneate or rotund, apex acute or acuminate and belongs to the family of Lauraceae which is one of 200 species. Litsea liyuyingi is one of the medicinal plants grown in Bangladesh mainly in tropical and subtropical Asia, a few species in Australia and from North America to subtropical South America and China. This plant has also been used in traditional medicine for the treatment of erectile dysfunction [6-7], urinary tract infection, sexually transmitted diseases, leucorrhoea, tonic, stimulant [8] and gestational diabetes [9]. Despite the popular use of this species as a medicinal plant; no previous attempts have been made to examine the biological activity of this plant.

As a part of our continuing studies on medicinal plants of Bangladesh the organic soluble materials of the leaf extracts of Litsea liyuyingi were evaluated for phytochemical screening, thrombolytic, membrane stabilizing, antibacterial, cytotoxic, antioxidant, anti-nociceptive, hypoglycemic and anti-diarrheal activity for the first time.

\subsection{Collection, identification and processing of plant samples}

\section{Materials And Methods}

The leaves of Litsea liyuyingi were collected from Bogra District, Bangladesh and then plant sample was submitted to the National Herbarium of Bangladesh, Mirpur-1, Dhaka for its identification and the voucher specimen is DACB- 42740. Leaves were sun dried for seven days in order to remove the moisture contents and 
then ground into coarse powder using high capacity grinding machine (Jaipan designer mixer grinder, jaipan, India) which was then stored in air-tight container with necessary markings for identification and kept in cool, dark and dry place for the investigation.

\subsection{Extraction procedure}

The powdered plant parts $(30 \mathrm{gm})$ were successively extracted in a soxhlet extractor at elevated temperature using $500 \mathrm{ml}$ of distilled methanol $(40-60)^{\circ} \mathrm{C}$. After drying all extracts, an aliquot $(5 \mathrm{gm})$ of the concentrated methanol extract was fractionated by the modified Kupchan et al. [10] into pet-ether, carbon tetrachloride and aqueous soluble fractions followed by solvent evaporation.

\subsection{Preliminary phytochemical screening}

Ethanol extract was subjected to preliminary phytochemical screenings for determining nature of phytoconstituents by using standard protocols [11-13].

\subsection{Streptokinase (SK)}

Commercially available lyophilized alteplase (Streptokinase) vial (Popular pharmaceutical Ltd.) of 15, 00,000 I.U, was collected and $5 \mathrm{ml}$ sterile distilled water was added and mixed properly. This suspension was used as a stock from which $100 \mu \mathrm{l}(30,000$ I.U) was used for in vitro thrombolytic activity evaluation.

\subsection{Blood sample}

Blood $(n=6)$ was drawn from healthy human volunteers without a history of oral contraceptive or anticoagulant therapy and $1 \mathrm{ml}$ of blood was transferred to the previously weighed micro centrifuge tubes and was allowed to form clots.

\subsection{Thrombolytic activity}

The thrombolytic activity of all extracts were evaluated by the method developed by Prasad et al. [14] and slightly modified by Sharif et al. [15] using streptokinase (SK) as the standard.

\subsection{Membrane stabilizing activity}

The membrane stabilization by hypotonic solution and heat-induced haemolysis method was used to assess anti-inflammatory activity of the plant extracts by following standard protocol. ${ }^{[16]}$ The erythrocyte membrane resembles to lysosomal membrane and as such, the effect of drugs on the stabilization of erythrocyte could be extrapolated to the stabilization of lysosomal membrane [17-18]. Membrane stabilizing activity of the extractives was assessed by using hypotonic solution-induced and heat-induced human erythrocyte haemolysis. To prepare the erythrocyte suspension, whole blood was obtained from healthy human volunteer and was taken in syringes (containing anticoagulant $3.1 \% \mathrm{Na}$ citrate). The blood was centrifuged and blood cells were washed three times with solution $(154 \mathrm{mM} \mathrm{NaCl})$ in $10 \mathrm{mM}$ sodium phosphate buffer ( $\mathrm{pH} 7.4)$ through centrifugation for $10 \mathrm{~min}$ at $3000 \mathrm{rpm}$.

\subsubsection{Hypotonic solution induced haemolysis}

The test sample consisted of stock erythrocyte (RBC) suspension $(0.5 \mathrm{ml})$ mixed with $5 \mathrm{~mL}$ of hypotonic solution $(50 \mathrm{mM} \mathrm{NaCl})$ in $10 \mathrm{mM}$ sodium phosphate buffered saline ( $\mathrm{pH} 7.4)$ containing either the extract $(1.0 \mathrm{mg} / \mathrm{ml})$ or acetyl salicylic acid (ASA) $(0.1 \mathrm{mg} / \mathrm{ml})$. The control sample consisted of $0.5 \mathrm{ml}$ of RBCs mixed with hypotonic-buffered saline alone. The mixture was incubated for $10 \mathrm{~min}$ at room temperature, centrifuged for $10 \mathrm{~min}$ at $3000 \mathrm{~g}$ and the absorbance of the supernatant was measured at $540 \mathrm{~nm}$.

The percentage inhibition of either haemolysis or membrane stabilization was calculated using the following equation:

$$
\% \text { inhibition of haemolysis }=100 \times\left(\mathrm{OD}_{1}-\mathrm{OD}_{2}\right) / \mathrm{OD}_{1}
$$

Where, $\mathrm{OD}_{1}=$ optical density of hypotonic-buffered saline solution alone (control)

$\mathrm{OD}_{2}=$ optical density of test sample in hypotonic solution

\subsubsection{Heat induced haemolysis}

Isotonic buffer containing aliquots $(5 \mathrm{ml})$ of the different extractives were put into two duplicate sets of centrifuge tubes. The vehicle, in the same amount, was added to another tube as control. Erythrocyte suspension was added to each tube and mixed gently by inversion. One pair of the tubes was incubated at $56^{\circ} \mathrm{C}$ for $30 \mathrm{~min}$ in 
a water bath, while the other pair was maintained at $(0-5){ }^{\circ} \mathrm{C}$ in an ice bath. The reaction mixture was centrifuged for $5 \mathrm{~min}$ at $2500 \mathrm{rpm}$ and the absorbance of the supernatant was measured at $560 \mathrm{~nm}$. equation:

The percentage inhibition or acceleration of hemolysis in tests and was calculated according to the

$$
\% \text { Inhibition of hemolysis }=100 \times\left[1-\left(\mathrm{OD}_{1}-\mathrm{OD}_{2}\right) /\left(\mathrm{OD}_{3}-\mathrm{OD}_{1}\right)\right]
$$

Where, $\mathrm{OD}_{1}=$ optical density of unheated test sample

$\mathrm{OD}_{2}=$ optical density of heated test sample

$\mathrm{OD}_{3}=$ optical density of heated control sample

\subsection{Antioxidant activity}

\subsubsection{Determination of total phenolic content}

Total phenolic content in the methanol and other extracts were determined by using the Folin-Ciocalteu reagent [19-20]. The plant extracts and standard were diluted by serial dilutions as $(6.25 \mu \mathrm{g} / \mathrm{ml}$ to $200 \mu \mathrm{g} / \mathrm{ml})$ then, on each test tube containing $1 \mathrm{ml}$ of a diluted solution of sample and standard, following reagent solutions were added $5 \mathrm{ml}$ folin-ciocalteu reagent (10 fold dilution) and $7.5 \%$ sodium carbonate $(4 \mathrm{ml})$. Test tube containing the standard solution and test tube containing extracts was incubated for 30 minutes and 60 minutes respectively at room temperature. Absorbance of samples and standard were measured at $765 \mathrm{~nm}$ using UV-VIS spectrophotometer against the blank. A typical blank solution contained the solvent used to dissolve the plant extract. The Total content of phenol compounds in plant extract was calculated as gallic acid equivalents (GAE) using the following equation:

$$
\mathrm{C}=(\mathrm{c} \times \mathrm{V}) / \mathrm{m}
$$

Where; $\mathrm{C}=$ total content of phenol compounds, $\mathrm{mg} / \mathrm{gm}$ plant extract, in GAE

$\mathrm{c}=$ the concentration of Gallic acid established from the calibration curve $(\mathrm{mg} / \mathrm{ml})$

$\mathrm{V}=$ the volume of extract in $\mathrm{ml}$

$\mathrm{m}=$ the weight of crude plant extract in $\mathrm{gm}$

\subsubsection{DPPH free radical scavenging assay}

The free radical scavenging capacities of the extracts were determined by using DPPH [21-22]. $1 \mathrm{ml}$ of plant extract or standard of different diluted $(6.25 \mu \mathrm{g} / \mathrm{ml}-800 \mu \mathrm{g} / \mathrm{ml})$ concentration solutions was taken in test tube and freshly prepared $2 \mathrm{ml}$ of $0.004 \%$ DPPH solution was added in each test tube to make the final volume 3 $\mathrm{ml}$. The mixture was incubated at room temperature for 30 minutes; the absorbance was read at $517 \mathrm{~nm}$ using a UV-VIS spectrophotometer. Ascorbic acid was used as standard. Control sample was prepared containing the same volume without any extract and standard. The absorbance was read at $517 \mathrm{~nm}$ using a UV-VIS spectrophotometer. Methanol was used as blank. Percent of inhibition of the DPPH free radical was measured by using the following equation:

$$
\% \text { inhibition }=\left(1-\mathrm{A}_{1} / \mathrm{A}_{0}\right) \times 100 \%
$$

Here, $A_{1}=$ Absorbance of the extract or standard

$\mathrm{A}_{0}=$ Absorbance of the control.

\subsection{Antibacterial activity}

The antibacterial screening, which is the first stage of antimicrobial drug discovery, was performed by the disc diffusion method against gram positive and gram negative bacteria (Table 5) collected as pure cultures from the department of microbiology, Dhaka University, Bangladesh. Standard disc of ciprofloxacin $(5 \mu \mathrm{g} / \mathrm{disc})$ and blank discs (impregnated with solvents followed by evaporation) were used as positive and negative control, respectively. The antimicrobial activity of the test agents was determined by measuring the diameter of zone of inhibition expressed in $\mathrm{mm}[23]$.

\subsection{Brine shrimp lethality bioassay}

Brine shrimp lethality bioassay technique was applied for the determination of general toxic properties of the plant extracts [24-25]. Dimethylsulfoxide (DMSO) solutions of the samples were applied against Artemia salina in 1 day for the assay. For the experiment, $1 \mathrm{mg}$ of each extracts was added with $5 \mathrm{ml}$ of sea water. Concentration was found to be $200 \mu \mathrm{g} / \mathrm{ml}$. Then $50 \mu 1$ DMSO was added to these and sample was prepared. 
Then the solution was serial diluted to $100,50,25,12.5,6.25,3.125,1.563 \mu \mathrm{g} / \mathrm{ml}$ with sea water. Then $2.5 \mathrm{ml}$ of plant extract solution was added to $2.5 \mathrm{ml}$ seawater containing 10 nauplii. Vincristine Sulphate (VS) was used as standard.

\subsection{Experimental animal}

For the experiment Swiss albino mice of either sex, 4-5 weeks of age, weighing between 15-30 gm were collected from ICDDR, B, Mohakhali, Dhaka, Bangladesh. Animals were maintained under standard environmental conditions [temperature: $(27.0 \pm 1.0)^{\circ} \mathrm{C}$, relative humidity: (55-65)\% and 12 hour light/12 hour dark cycle] and free access to feed and water. The animals were acclimatized to laboratory condition for one week prior to experiments. All protocols for animal experiment were approved by the institutional animal ethical committee.

\subsection{Anti-nociceptive activity}

Anti-nociceptive activity was evaluated by acetic acid induced writhing and tail immersion methods.

\subsubsection{Acetic acid induced writhing test}

The acetic acid writhing test in mice as described by Koster et al. [26] was employed with slight modification. Mice were divided into 4 groups containing 5 mice in each group. The first group was given 10 $\mathrm{ml} / \mathrm{kg}$ of $1 \%$ Tween 80 intraperitoneally and served as control. Group 2 was served as standard where diclofenac $\mathrm{Na}$ has given to mice as dose of $50 \mathrm{mg} / \mathrm{kg}$ of body weight. Groups 3, 4 received methanol extracts $200 \mathrm{mg} / \mathrm{kg}$ and $400 \mathrm{mg} / \mathrm{kg}$ of body weight. Thirty minutes later each mouse was injected intraperitoneally with $0.7 \%$ acetic acid at doses of $10 \mathrm{ml} / \mathrm{kg}$ of body weight. Full writhing was not always completed by the mice. Accordingly, two half writhing were considered as one full writhing. The number of writhing responses was recorded for each mouse during a subsequent 5 min period after $15 \mathrm{~min}$ intra peritoneal administration of acetic acid and the mean abdominal writhing for the each group was obtained and recorded.

\subsubsection{Tail immersion test}

The tail immersion method was used to evaluate the central mechanism of analgesic activity. Here the painful reactions in animals were produced by thermal stimulus that is by dipping the tip of the tail in hot water [27]. On the test day, Swiss albino mice were divided into 4 groups of 5 mice each. Here diclofenac $\mathrm{Na}$ (50 $\mathrm{mg} / \mathrm{kg}$ ) is used as standard drug as well. Animals were fasted for 16 hours with free access to water. After administration of standard and test drugs, the basal reaction time was measured by immersing the tail tips of mice (last $1-2 \mathrm{~cm}$ ) in hot water of water bath, where temperature was previously adjusted at $51^{\circ} \mathrm{C}$. The actual flick response of mice that is time taken in second to withdraw it from hot water source was calculated and results were compared with control group. The latent period of the tail-flick response was determined at 30,60 and 90 minute after the administration of drugs.

\subsection{In vivo anti-diarrheal activity test}

The present study was performed to evaluate the preventive and curative anti-diarrheal effects of the methanol extracts at two different concentrations. All the animals housed under standard laboratory condition at $25^{\circ} \mathrm{C}$ and 12 hour light such as dark cycle, acclimatized for 10 days before experiment. Standard diet and water were provided constantly. When test started all organized groups served with their respective doses and standard group served with loperamide $(5 \mathrm{mg} / \mathrm{kg}$ ) doses. After 1 hour, all groups received castor oil $2 \mathrm{ml}$ each orally. Then they were placed in cages lined with adsorbent papers and observed for 4 hour for the presence of characteristic diarrheal droppings. $100 \%$ was considered as the total number of feces of control group. The activity was expressed as percent inhibition of diarrhea [28-29].

\subsection{Hypoglycemic activity}

The aim of this hypoglycemic activity study was to evaluate hypoglycemic activity in normal mice [30]. The experimental mice were fasted for 12 hours, and then randomly selected and divided into 4 groups of 5 mice in each group. At zero hour, fasting blood glucose level was measured in each group from tail vein prior to the glucose administration by using glucometer with glucose oxidase-peroxidase reactive strips. Control vehicle (1\% Tween-80 solution in saline), standard drug (glibenclamide) at dose of $10 \mathrm{mg} / \mathrm{kg}$ of body weight) and extracts (200 and $400 \mathrm{mg} / \mathrm{kg}$ of body weight) were administered to Group 1, 2, 3 and 4 respectively using oral feeding needle. After $60,120 \& 180 \mathrm{~min}$, blood samples were collected in the same procedure and blood glucose level is measured to see the hypoglycemic effect in comparison with control and standard groups.

\subsection{Statistical analysis}

Data was expressed as Mean \pm Standard deviation. Results below $* p<0.05$, $* * p<0.01$ and $* * * p<0.001$ are considered statistically significant. 


\subsection{Preliminary phytochemical screening}

\section{Results}

Preliminary phytochemical screening of the methanol extract of L. liyuyingi revealed either presence or absence of various bioactive components. L. liyuyingi was found to contain flavonoids, saponins, alkaloids, phenols and tannins (Table 1).

Table 1: Analysis of phytochemicals in the methanol extracts of L. liyuyingi

\begin{tabular}{|c|c|}
\hline Name of tests & Name of extract \\
\hline Flavonoids & + \\
\hline Saponins & + \\
\hline Alkaloids & + \\
\hline Phenols & + \\
\hline Tannins & + \\
\hline
\end{tabular}

(+) Presence

\subsection{Thrombolytic activity}

In thrombolytic activity using in vitro clot lysis assay method, prominent thrombolysis was demonstrated by the crude methanol extract $43.55 \%$ and its pet-ether fraction $42.11 \%$ compared to standard $65.16 \%$. The thrombolytic activity of the plant extractives is presented in Table 2.

Table 2: In vitro thrombolytic activity of different extractives of L. liyuyingi

\begin{tabular}{|c|c|}
\hline Samples & \% of clot lysis \\
\hline Crude Methanol Extracts & $43.55 \%$ \\
\hline Pet-ether Soluble Fraction & $42.11 \%$ \\
\hline Carbon Tetrachloride Soluble Fraction & $12.59 \%$ \\
\hline Aqueous Soluble Fraction & $21.20 \%$ \\
\hline Control & $8.20 \%$ \\
\hline Streptokinase & $65.16 \%$ \\
\hline
\end{tabular}

\subsection{Membrane stabilizing activity}

The crude methanol extract of $L$. liyuyingi, as well as different soluble fractions derived from this extract, were subjected to assay for membrane stabilizing activities following standard protocols and the obtained results were represented in Table 3. For hypotonic solution induced haemolysis, at a concentration of $1.0 \mathrm{mg} / \mathrm{ml}$ the highest level of membrane stabilizing activity was exhibited by the carbon tetrachloride fraction $88.78 \%$, whereas acetyl salicylic acid inhibited $71.91 \%$. On the other hand, during heat induced condition aqueous fractions of L. liyuyingi demonstrated highest inhibition $(94.24 \%)$ of haemolysis of RBCs, which was even higher than acetyl salicylic acid and crude methanol extracts.

Table 3: Membrane stabilizing activity of different extractives of L. liyuyingi

\begin{tabular}{|c|c|c|}
\hline \multirow{2}{*}{ Samples } & \multicolumn{2}{|c|}{ \% Inhibition of haemolysis } \\
\cline { 2 - 3 } & Hypotonic solution induced & Heat induced \\
\hline Crude Methanol Extracts & 59.19 & 46.53 \\
\hline Pet-ether Soluble Fraction & 81.33 & 34.75 \\
\hline Carbon Tetrachloride Soluble Fraction & 88.78 & 49.33 \\
\hline Aqueous Soluble Fraction & 79.47 & 94.24 \\
\hline Acetyl salicylic acid & 71.91 & 77.23 \\
\hline
\end{tabular}

\subsection{Antioxidant activity}

\subsubsection{Determination of total phenolic content}

Total phenolic content of the different extracts was determined by using the Folin-Ciocalteu reagent and were expressed as Gallic Acid Equivalents (GAE) per gram of plant extract. Among all extractives of $L$. liyuyingi, the highest concentration of phenols was found in crude methanol extracts (200 mg of GAE/gm of extractives) followed by pet-ether, carbon tetrachloride and aqueous soluble fraction (Table 4).

Table 4: Total phenolic content of different extractives of L. liyuyingi

\begin{tabular}{|c|c|}
\hline Samples & $\begin{array}{c}\text { Total phenolic content } \\
\text { (mg of GAE / gm of extractives) }\end{array}$ \\
\hline Crude Methanol Extracts & 200 \\
\hline Pet-ether Soluble Fraction & 16.56 \\
\hline Carbon Tetrachloride Soluble Fraction & 132.19 \\
\hline Aqueous Soluble Fraction & 135.19 \\
\hline
\end{tabular}




\subsubsection{DPPH free radical scavenging assay}

The $\mathrm{IC}_{50}$ values of different extracts of L. liyuyingi are presented in table 5. $\mathrm{IC}_{50}$ of ascorbic acid was found $2.57 \mu \mathrm{g} / \mathrm{ml}$. In comparison to standard, pet-ether, carbon tetrachloride, aqueous fractions and crude methanol extracts showed $\mathrm{IC}_{50}$ values of $51.70,11.98,7.75$ and $2.61 \mu \mathrm{g} / \mathrm{ml}$ respectively (Table 5).

Table 5: $\mathrm{IC}_{50}$ values of different extractives of L. liyuyingi and standard of DPPH free radical scavenging assay

\begin{tabular}{|c|c|}
\hline Samples & $\mathbf{I C}_{\mathbf{5 0}}$ value $(\boldsymbol{\mu} \mathbf{g} / \mathbf{m l})$ \\
\hline Crude Methanol Extracts & 2.61 \\
\hline Pet-ether Soluble Fraction & 51.70 \\
\hline Carbon Tetrachloride Soluble Fraction & 11.98 \\
\hline Aqueous Soluble Fraction & 7.75 \\
\hline Ascorbic Acid & 2.57 \\
\hline
\end{tabular}

\subsection{Antibacterial activity}

The crude methanol extract of $L$. liyuyingi, as well as different soluble fractions derived from this extract, were subjected to assay for antibacterial activity following standard protocols and the obtained results were represented in Table 6 . The different fractions $(1000 \mu \mathrm{g} / \mathrm{disc})$ of $L$. liyuyingi were screened against four gram positive and five gram negative bacteria where ciprofloxacin was used as standard and showed zone of inhibition, ranging from (36-42) $\mathrm{mm}$ in diameter. Crude methanol extract and its fractions showed more or less inhibition against selected microorganisms (bacteria).

Table 6: Antibacterial activity by disc diffusion assay

\begin{tabular}{|c|c|c|c|c|c|}
\hline \multirow[b]{2}{*}{ Bacterial isolates } & \multicolumn{5}{|c|}{ Zone of inhibition in diameter (mm) } \\
\hline & $\begin{array}{c}\text { Crude } \\
\text { methanol } \\
\text { extracts }\end{array}$ & $\begin{array}{c}\text { Pet-ether } \\
\text { soluble } \\
\text { fraction }\end{array}$ & $\begin{array}{l}\text { Carbon tetrachloride } \\
\text { soluble fraction }\end{array}$ & $\begin{array}{l}\text { Aqueous } \\
\text { soluble } \\
\text { fraction }\end{array}$ & Ciprofloxacin \\
\hline \multicolumn{6}{|l|}{ Gram positive bacteria } \\
\hline Bacillus cereus & 12 & - & 7 & 8 & 40 \\
\hline Bacillus subtilis & 10 & 8 & 13 & - & 40 \\
\hline Staphylococcus aureus & 10 & 9 & 16 & - & 37 \\
\hline Sarcina lutea & 16 & - & 14 & 10 & 36 \\
\hline \multicolumn{6}{|l|}{ Gram negative bacteria } \\
\hline Escherichia coli & 11 & 7 & 16 & 5 & 40 \\
\hline Salmonella typhi & 10 & 15 & 16 & - & 37 \\
\hline Shigella dysenteriae & 17 & - & 17 & - & 30 \\
\hline Vibrio mimicus & 17 & 8 & 13 & - & 42 \\
\hline Vibrio parahemolyticus & 13 & 10 & 17 & 8 & 38 \\
\hline
\end{tabular}

\subsection{Brine shrimp lethality bioassay}

In the brine shrimp lethality bioassay the $\mathrm{LC}_{50}$ and $\mathrm{LC}_{90}$ value of the test samples after 24 hours was obtained by a plot of percentage of the shrimps died against the logarithm of the sample concentration. The bestfit line was obtained from the curve data by means of regression analysis. Vincristine sulfate was used as positive control and the $\mathrm{LC}_{50}$ and $\mathrm{LC}_{90}$ were found to be $0.45 \mu \mathrm{g} / \mathrm{ml}$ and $8.97 \mu \mathrm{g} / \mathrm{ml}$ respectively. The $\mathrm{LC}_{50}$ and $\mathrm{LC}_{90}$ value of different extractives of $L$. liyuyingi are represented in Table 7.

Table 7: $\mathrm{LC}_{50}$ and $\mathrm{LC}_{90}$ values of different extractives of L. liyuyingi

\begin{tabular}{|c|c|c|}
\hline Samples & $\mathbf{L C}_{\mathbf{5 0}}$ value $(\mu \mathbf{g} / \mathbf{m l})$ & $\mathbf{L C}_{\mathbf{9 0}}$ value $(\boldsymbol{\mu g} / \mathbf{m l})$ \\
\hline Crude Methanol Extracts & 9.14 & 82.14 \\
\hline Pet-ether Soluble Fraction & 1.04 & 32.28 \\
\hline Carbon Tetrachloride Soluble Fraction & 0.85 & 30.20 \\
\hline Aqueous Soluble Fraction & 9.41 & 34.14 \\
\hline Vincristine sulfate & 0.45 & 8.97 \\
\hline
\end{tabular}

\subsection{Anti-nociceptive activity test}

The anti-nociceptive activity of methanol extract of L. liyuyingi was tested by using two models (acetic acid-induced, tail immersion test) so that both the centrally and peripherally mediated effects could be investigated.

\subsubsection{Acetic acid induced writhing test}

In acetic acid-induced writhing test, methanol extracts of L. liyuyingi induced a significant decrease in the number of writhing and produced $45.73 \%(* * \mathrm{p}<0.01)$ and $42.83 \%(* * \mathrm{p}<0.01)$ writhing inhibition at the doses of 200 and $400 \mathrm{mg} / \mathrm{kg}$ body weight respectively, which was comparable to the standard drug diclofenac $\mathrm{Na}$ where the inhibition was $65.71 \%$ at the dose of $10 \mathrm{mg} / \mathrm{kg}$ body weight (Table 8 ). 
Table 8: Effect of the methanol extracts using acetic acid-induced writhing test

\begin{tabular}{|c|c|c|}
\hline Groups & No. of writhing & \% Inhibition \\
\hline Control & $11.67 \pm 1.2$ & - \\
\hline Diclofenac Na $10 \mathrm{mg} / \mathrm{kg}$ & $4.00 \pm 1.5 * * *$ & 65.71 \\
\hline Methanol Extract $200 \mathrm{mg} / \mathrm{kg}$ & $6.33 \pm 1.20^{* *}$ & 45.74 \\
\hline Methanol Extract $400 \mathrm{mg} / \mathrm{kg}$ & $6.67 \pm 1.45^{* *}$ & 42.83 \\
\hline
\end{tabular}

Values are expressed as mean $\pm \mathrm{SD}(\mathrm{n}=5),{ }^{*} \mathrm{p}<0.05 ; * * \mathrm{p}<0.01 ; * * * \mathrm{p}<0.001$; significant when compared with the corresponding value of control

\subsubsection{Tail immersion test}

In vivo anti-nociceptive activity test was done on $200 \mathrm{mg} / \mathrm{kg}$ and $400 \mathrm{mg} / \mathrm{kg}$ doses of methanol extracts of L. liyuyingi leaf, which were presented in (Table 9). Both the doses (200 and $400 \mathrm{mg} / \mathrm{kg}$ body weight) of methanol significantly $(* * * \mathrm{p}<0.001)$ raised pain threshold from $30 \mathrm{~min}$ up to $60 \mathrm{~min}$ when compared with control. Both extracts showed decreased pain with dose dependently like the standard diclofenac Na.

Table 9: Tabular representation of anti-nociceptive activity through tail immersion test

\begin{tabular}{|c|c|c|c|}
\hline \multirow{2}{*}{ Group } & \multicolumn{3}{|c|}{ Latency time (Sec) } \\
\cline { 2 - 4 } & 30 minute & 60 minute & 90 minute \\
\hline Control & $2.03 \pm 0.16$ & $2.63 \pm 0.22$ & $3.03 \pm 0.13$ \\
\hline Diclofenac Na $50 \mathrm{mg} / \mathrm{kg}$ & $3.87 \pm 0.27 * * *$ & $4.62 \pm 0.38 * * *$ & $4.73 \pm 0.109 * * *$ \\
\hline Methanol extract $200 \mathrm{mg} / \mathrm{kg}$ & $3.99 \pm 0.37 * * *$ & $4.89 \pm 0.51 * * *$ & $5.39 \pm 0.77 * *$ \\
\hline Methanol extract $400 \mathrm{mg} / \mathrm{kg}$ & $3.63 \pm 0.21 * * *$ & $3.79 \pm 0.11 * * *$ & $5.35 \pm 0.44 * * *$ \\
\hline
\end{tabular}

Values are expressed as mean $\pm \mathrm{SD}(\mathrm{n}=5), * \mathrm{p}<0.05 ; * * \mathrm{p}<0.01 ; * * * \mathrm{p}<0.001$; significant when compared with the corresponding value of control

\subsection{Anti-diarrheal activity}

The crude methanol extracts of L. liyuyingi were subjected to assay for anti-diarrheal activity following standard protocols and the obtained results were represented in Table 10. The present study revealed that the both doses of methanol extracts and standard drug showed significant activity $(* * p<0.01)$ when compared to control (1\% Tween-80 solution in saline).

Table 10: Effect of methanol extracts of L. liyuyingi using castor oil induced anti-diarrheal activity test

\begin{tabular}{|c|c|c|}
\hline Groups & No. of writhing & \% Inhibition \\
\hline Control & $4.67 \pm 1.33$ & - \\
\hline Loperamide $5 \mathrm{mg} / \mathrm{kg}$ & $1.67 \pm 0.33^{* *}$ & 64.24 \\
\hline Methanol Extract $200 \mathrm{mg} / \mathrm{kg}$ & $3.00 \pm 0.58^{*}$ & 35.76 \\
\hline Methanol Extract $400 \mathrm{mg} / \mathrm{kg}$ & $2.67 \pm 0.33^{*}$ & 42.83 \\
\hline
\end{tabular}

Values are expressed as mean $\pm \mathrm{SD}(\mathrm{n}=5),{ }^{*} \mathrm{p}<0.05 ; * * \mathrm{p}<0.01 ; * * * \mathrm{p}<0.001$; significant when compared with the corresponding value of control

\subsection{Hypoglycemic activity}

The crude methanol extracts of $L$. liyuyingi were subjected to assay for hypoglycemic activity following standard protocols and the obtained results were represented in Table 11. The methanol extracts of $L$. liyuyingi has statistically significant blood glucose lowering activity at dose of $200 \& 400 \mathrm{mg} / \mathrm{kg}$.

Table 11: Effect of methanol extracts of L. liyuyingi using hypoglycemic activity test in mice

\begin{tabular}{|c|c|}
\hline Groups & Plasma level of glucose \\
\hline Control & $6.63 \pm 0.27$ \\
\hline Glibenclamide & $4.65 \pm 0.49 * *$ \\
\hline Methanol Extract $200 \mathrm{mg} / \mathrm{kg}$ & $5.72 \pm 0.53 *$ \\
\hline Methanol Extract $400 \mathrm{mg} / \mathrm{kg}$ & $5.80 \pm 0.04 * *$ \\
\hline
\end{tabular}

Values are expressed as mean $\pm \mathrm{SD}(\mathrm{n}=5),{ }^{*} \mathrm{p}<0.05 ; * * \mathrm{p}<0.01 ; * * * \mathrm{p}<0.001$; significant when compared with the corresponding value of control

\section{Discussion}

A large proportion of drugs in clinical use are produced by the synthesis of natural products and/or their derivatives, and new plant-derived medicines are continually being discovered as the herbal remedies are cost effective, having minimum toxicity with reduced health hazards and easily available in market as compared to synthetic medicines. By recombinant DNA technology several thrombolytic drugs are developed but site specificity with fewer side effects of thrombolytic drugs are desirables in natural thrombolytic product [31]. As a part of discovery of cardio-protective drugs from natural sources the extractives of L. liyuyingi were assessed for thrombolytic activity where the comparison of streptokinase with water clearly confirmed that clot dissolution 
does not occur when water was added to the clot and a significant thrombolytic activity was observed after treating the clots with L. liyuyingi.

Membrane stabilization assay of erythrocytes is a very popular tool to investigate the anti-inflammatory potential of the plant extract. A possible explanation for the stabilizing activity of the present study of the extractives may be due to an increase in the surface area/volume ratio of the cells which could be brought about by an expansion of membrane or shrinkage of the cell and an interaction with membrane proteins [32]. Several flavonoids and triterpenes have been reported earlier to have anti-inflammatory activity [33-34]. As flavonoids are present in L. liyuyingi, it might be a reason for its membrane stabilizing anti-inflammatory potential.

Ascorbic acid had been reported to exhibit greater potential antioxidant activity [21, 35]. The phenomenon in this study is acceptable since ascorbic acid has the highest inhibition percentage inhibits free radical activity. The greater the decolorizing action, upon reduction by either the process of hydrogen or electron donation, the higher the antioxidant activity and is reflected by lower $\mathrm{IC}_{50}$ value. Substances which are able to perform this reaction can be considered as antioxidants and, therefore, radical scavengers. In the present study, all the plant extracts showed dose dependent scavenging of DPPH free radicals in a way similar to that of the standard antioxidant ascorbic acid. Presence of total phenol content and flavonoid in the plant extracts may be a reason for this DPPH-scavenging activity [35]. According to Odabasoglu et al. [36] there is high correlation between antioxidant activity and phenolics content as the phenolics constituents can react with active oxygen radicals such as hydroxyl radical [37], superoxide anion radical [38] and lipid peroxy radical [39]. The presence of phenolic content in L. liyuyingi extract may be responsible for such high antioxidant potentials.

Antimicrobial therapy markedly reduces the morbidity and mortality, emergence of resistance to first line antibiotics poses challenge in treatment of several human infections [40-42] and is prompting a revival in research of the antimicrobial role of plants against resistant strains due to comparable safety and efficacy. Crude methanol and carbon tetrachloride soluble fractions of leaf extracts of L. liyuyingi showed a moderate range of antibacterial activity against all selected gram positive and gram negative microorganisms at the concentration of $1000 \mu \mathrm{g} / \mathrm{ml}$, whereas the range of zone of inhibition was within (7-17) mm (Table. 6). Kunle and Egharevba, [43] suggested to consider the presence of flavonoids in a plant as indication of its antioxidant, antiallergic, antiinflammatory, antimicrobial and anticancer properties.

The findings of this study suggest that there may be cytotoxic compounds in L. liyuyingi leaf extracts that can induce the cytotoxic action against cancer cells and initiate antiproliferation effect leading to cancer cell death. The cytotoxicity of plant material would indicate the presence of antitumour compounds in plant extract [44]. In the present study, carbon tetrachloride fraction $\left(\mathrm{LC}_{50}=0.85 \mu \mathrm{g} / \mathrm{ml}, \mathrm{LC}_{90}=30.20 \mu \mathrm{g} / \mathrm{ml}\right)$ revealed most cytotoxicity in comparison with positive standard of vincristine sulfate $\left(\mathrm{LC}_{50}=0.45 \mu \mathrm{g} / \mathrm{ml}, \mathrm{LC}_{90}=8.97 \mu \mathrm{g} / \mathrm{ml}\right)$. Crude extracts resulting in $\mathrm{LC}_{50}$ values less than $250 \mu \mathrm{g} / \mathrm{ml}$ could be considered active and potential for further investigation [45-46].

The analgesic effect of any plant extract reducing the number of writhing will render analgesic effect preferably by inhibition of prostaglandin synthesis, a peripheral mechanism of pain inhibition [47]. In acetic acid induced writhing test and tail immersion test, methanol extracts of both doses of L. liyuyingi induced a significant $(* * p<0.01)$ decrease in the number of writhing and significantly $(* * * p<0.001)$ raised pain threshold from $30 \mathrm{~min}$ up to $60 \mathrm{~min}$ when compared with control respectively. According to phytochemical screening, this anti-nociceptive effect of the leaf extract can be due to the presence of alkaloid, quinine and coumarin which is known to give analgesic effects in-vivo [48].

Diarrhea is one of the most common causes for thousands of deaths every year. Therefore, identification of new source of anti-diarrheal drugs becomes one of the most prominent focuses in modern research. The present study revealed that the activity of methanol extract was increased in a dose dependent manner.

Any drug that is effective in diabetes will have the ability to control the glucose level by different mechanisms. Methanol extract of L. liyuyingi exhibited significant antihyperglycemic activity at a dose level of 200 and $400 \mathrm{mg} / \mathrm{kg}$; whereas the blood glucose lowering activity of glibenclamide was 4.65 plasma level of glucose (Table 11). 


\section{Conclusion}

All the conducted experiments in the present study are based on crude extract and different soluble fractions are considered to be preliminary and more sophisticate research is necessary to reach a concrete conclusion about the findings of the present study. It can be concluded from the above findings, the plant $L$. liyuying $i$ have moderate to significant thrombolytic, membrane stabilizing, antioxidant, antimicrobial, cytotoxic, analgesic, anti-diarrheal and hypoglycemic activity. So, further scientific studies are necessary to elucidate detailed mechanism of action and isolate the responsible active principles.

\section{References}

[1]. Demrow HS, Slane PR, Folts JD. Administration of wine and grape juice inhibits in vivo platelet activity and thrombosis in stenosed canine coronary arteries. Circulation, 91, 1995, 1182-1188.

[2]. Sofowora A, Ogunbodede E, Onayad A. The role and place of medicinal plants in the strategies for disease prevention. African Journal of Traditional, Complementary and Alternative medicines, 10(5), 2013, 210-229.

[3]. Halliwell B, Gutteridge JMC. Free radicals, antioxidants and human diseases. Where are we now? Journal of Laboratory and Clinical Medicine, 119, 1992, 598-620.

[4]. Malorni W, Rivabene R, Lucia BM, Ferrara R, Mazzone AM, Cauda R, Paganelli R. The role of oxidative imbalance in progression to AIDS: effect of the thiol supplier N-acetylcysteine. AIDS Research and Human Retroviruses, 14, 1998, 1589-1596.

[5]. Koleva II, Niederlander HAG, Van Beek TA. An online HPLC method for detection of radical scavenging compounds in complex mixtures. Analytical Chemistry, 72, 2000, 2323-2328.

[6]. Rahmatullah M, Mollik MAH, Khatun MA, Jahan R, Chowdhury AR, Seraj S, Hossain MS, Nasrin D, Khatun Z. A Survey on the Use of Medicinal Plants by Folk Medicinal Practitioners in Five Villages of Boalia Sub-district, Rajshahi District, Bangladesh. Advances in Natural and Applied Sciences, 4(1), 2010, 39-44.

[7]. Rahmatullah M, Mollik MAH, Islam MK, Islam MR, Jahan FI, Khatun Z, Seraj S, Chowdhury MH, Islam F, Miajee ZUME, Jahan R. A survey of medicinal and functional food plants used by the folk medicinal practitioners of three villages in Sreepur Upazilla, Magura District, Bangladesh. American-Eurasian Journal of Sustainable Agriculture, 4(3), 2010, 363-373.

[8]. Hossan MS, Agarwala B, Sarwar S, Karim M, Jahan R, Rahmatullah M. Traditional use of medicinal plants in Bangladesh to treat urinary tract infections and sexually transmitted diseases. Ethnobotany Research \& Application, 8, 2010, 061-074.

[9]. Mollik MAH. 715 use of medicinal plants for gestational diabetes in Bangladesh: A pragmatic randomized ethnopharmacological survey in Narail District. Pediatric Research, 68, 2010, 362-362.

[10]. Kupchan SM, Britton RW, Ziegler MF, Sigel CW. Bruceantin, a new potent antileukemic simaroubolide from Brucea antidysenterica. The Journal of Organic Chemistry, 38(1), 1973, 178-179.

[11]. Tiwari P, Kumar B, Kaur M, Kaur G, Kaur H. Phytochemical screening and extraction: A review. Internationale Pharmaceutica Sciencia, 1, 2011, 103-104

[12]. Ghani A. Medicinal Plants of Bangladesh. $1^{\text {st }}$ edition. Bangladesh: Dhaka, 1998.

[13]. Evans WC. Trease, Evan's Textbook of Pharmacognosy. $13^{\text {th }}$ edition. London: Cambidge University Press, 1989.

[14]. Prasad S, Kashyap RS, Deopujari JY, Purohit HJ, Taori GM, Daginawala HF. Development of an in vitro model to study clot lysis activity of thrombolytic drugs. Thrombosis Journal, 4, 2006, 14

[15]. Sharif S, Ahmed T, Haque MA, Bhuiyan MA, Shahriar M. Phytochemical screenings, thrombolytic activity, membrane stabilizing activity and cytotoxic properties of Polygonum hydropiper. Research Journal of Medicinal Plant, 8(2), 2014, 92-98.

[16]. Shinde UA, Phadke AS, Nair AM, Mungantiwar AA, Dikshit VJ, Saraf MN. Membrane stabilizing activity - a possible mechanism of action for the anti-inflammatory activity of Cedrus deodara wood oil. Fitoterapia, 70, 1999, 251-257.

[17]. Omale J, Okafor PN. Comparative antioxidant capacity, membrane stabilization, polyphenol composition and cytotoxicity of the leaf and stem of Cissus multistriata. African Journal of Biotechnology, 7, 2008, 3129-3133.

[18]. Shahriar M, Khair NZ, Sheikh Z, Chowdhury SF, Kamruzzaman M, Bakhtiar MSI et al. Characterization of phytoconstituents and potential bioactivity of Annona reticulata L. leaf extract. Journal of Pharmacognosy and Phytochemistry, 5(1), 2016, 42-45.

[19]. Velioglu YS, Mazza G, Gao YL, Oomah BD. Antioxidant activity and total phenolics in selected fruits, vegetables and grain products. Journal of Agricultural and Food Chemistry, 46, 1998, 4413- 4417.

[20]. Demiray S, Pintado ME, Castro PML. Evaluation of phenolic profiles and antioxidant activities of Turkish medicinal plants: Tilia argentea, Crataegi folium leaves and Polygonum bistorta roots. World Academy of Science, Engineering and Technology, 54, 2009, 312- 317 .

[21]. Ahmed T, Akter R, Sharif S, Shahriar M, Bhuiyan MA. In vitro antioxidant activities and In vivo anti-nociceptive and neuropharmacological activities of Mimosa pudica. International Journal of Pharmacy, 4(2), 2014, 70-78.

[22]. Shafa F, Shahriar M, Opo FADM, Akhter R, Hossain MMH, Choudhury N. Characterization of phytoconstituents, in vitro antioxidant activity and pharmacological investigation of the root extract of Typhonium trilobatum. International Journal of Pharmaceutical Sciences and Research, 7(4), 2016, 1694-1704.

[23]. Bauer AW, Kirby WMM, Sherries JC, Tuck M. Antibiotic susceptibility testing by a standardized disc diffusion method. American Journal of Clinical Pathology, 45, 1966, 493-496.

[24]. Meyer BN, Ferrigni NR, Putnam JE, Jacobsen JB, Nicholsand DE, Mclaughlin JL. Brine shrimp: A convenient general bioassay for active plant constituents. Planta Medica, 45(5), 1982, 31-34.

[25]. Shahriar M, Khair NZ, Sheikh Z, Chowdhury SF, Kamruzzaman M, Bakhtiar MSI et al. Phytochemical analysis, cytotoxic and in vitro antioxidant activity of Erythrina variegate bark. European Journal of Medicinal Plants, 11(3), 2016, 1-5.

[26]. Koster R, Anderson M, DeBeer E. Acetic acid for analgesic screening. Federation Proceedings, 18, 1959, $412-418$.

[27]. Luiz CDS, Mirtes C, Sigrid LJ, Mizuekirizawa M, Cecilia G, Jrotin G. Analgesic activity by tail immersion method. Journal of Ethnopharmacology, 24, 1988, 205-211.

[28]. Rahman MK, Chowdhury MAU, Islam MT, Chowdhury MA, Uddin ME and Sumi CD. Evaluation of antidiarrheal activity of methanolic extract of Maranta arundinacea Linn. leaves. Advance Pharmacological Science, 2015, 2015, 1-6.

[29]. Opo FADM, Das S, Khandokar S, Akhter R, Shahriar M. In vivo pharmacological investigations of leaf extracts of calamus tenuis Roxb. International Journal of Pharmaceutical Research and Bio Science, 5(4), 2016, 1-12.

[30]. Andrade-Cetto A, Heinrich M. Mexican plants with hypoglycaemic effect used in the treatment of diabetes. Journal of Ethnopharmacology, 99, 2005, 325-48.

[31]. Hussain F, Islam M, Bulbul L, Moghal MMR, Hossain MS. In vitro thrombolytic potential of root extracts of four medicinal plants available in Bangladesh. Ancient Science of Life, 33(3), 2014, 162-164. 
[32]. Bakhtiar MSI, Akhter R, Narjish SN, Chisty SJ, Shahriar M, Bhuiyan MA. In vitro and in vivo biological investigations of the whole plant extracts of Chrozophora prostrata (Dalz.). International Journal of Pharmacy, 5(4), 2015, 1188-1195.

[33]. Serafini M, Peluso I, Raguzzini A. Flavonoids as anti-inflammatory agents. Proceedings of the Nutrition Society, 69, 2010, 273278.

[34]. Safayhi H, Sailer E. Anti-inflammatory actions of pentacyclic triterpenes. Planta Medica, 63, 1997, 487-93.

[35]. Hossain MS, Niloy SA, Hosen A, Islam MAU, Islam Z, Das S, Hassan MA, Islam AFMM, Rana MS. Antioxidant Activities and HPLC-DAD Based Phenolic Content Determination of Bauhinia scandens. British Journal of Pharmaceutical Research, 14(6), 2016, 1-9.

[36]. Odabasoglu F, Aslan A, Cakir A, Suleyman H, Karagoz Y. Comparison of antioxidant activity and phenolic content of three lichen species. Phytotherapy Research, 18(11), 2004, 938-941.

[37]. Hussain SR, Cillard J, Cillard P. Hydroxyl radical scavenging activity of flavonoids. Phytochemistry, 26, $1987,2489$.

[38]. Afanaslev IB, Dorozhko AI, Bordskii AV. Chelating and free radical scavenging mechanisms of inhibitory action of rutin and quercetin in lipid peroxidation. Biochemical Pharmacology, 38, 1989, 1763.

[39]. Torel J, Cillard J, Cillard P. Antioxidant activityof flavonoidsand reactivity with peroxy radicals. Phytochemistry, 25, $1986,383$.

[40]. Soma LJ, Shahriar M, Narjish SN, Bhuiyan MA. Antimicrobial resistance pattern of bacteria isolated from ICU Patients with respiratory tract infections. Dhaka University Journal of Pharmaceutical Sciences, 13(2), 2014, 193-197.

[41]. Ferdousi R, Narjish SN, Chowdhury D, Shahriar M. Antimicrobial resistance pattern of bacteria isolated from ICU patients with urinary tract infections. International Journal of Pharmaceutics, 5(4), 2015, 1079-1086.

[42]. Das S, Shahriar M, Narjish SN, Akhter R. In vitro investigation on antimicrobial sensitivity pattern of enteric fever causing bacteria isolated from different clinical sources in Dhaka city, Bangladesh. International Journal of Medical and Health Research, 2(5), 2016, 33-37.

[43]. Kunle OF, Egharevba HO. Preliminary studies on Vernonia ambigua, phytochemistry and antimicrobial screening of whole plant. Ethnobotanical Leaflets, 13, 2009, 1216-1221.

[44]. Martin-Cordero G, Saenz MT, Ayuso MJ. Cytotoxic activity of Retama spaerocarpa. Fitoterapia, 16, 1995, $495-498$.

[45]. Rieser MJ, Gu ZM, Fang XP, Zeng L, Wood KV, McLaughlin JL. Five novel mono-tetrahydrofuran ring acetogenins from the seeds of Annona muricata. Journal of Natural Products, 59, 1996, 100-108.

[46]. Laboni FR, Sultana T, Kamal S, Karim S, Das S, Harun-Or-Rashid M, Shahriar M. Biological investigations of the ethanol extract of the aerial part (leaf) of Coccinia grandis L. Journal of Pharmacognosy and Phytochemistry, 6(2), 2017, $134-138$.

[47]. Khandaker S, Das S, Opo FADM, Akhter R, Shahriar M. In vivo pharmacological investigations of the crude extracts of Calamus viminalis (L.). Journal of Pharmacognosy and Phytochemistry, 5(3), 2016, 263-269.

[48]. Aziz U, Akther R, Shahriar M, Bhuiyan MA. In vivo pharmacological investigation of Mimosa pudica (L.). International Journal of Pharmacy and Pharmaceutical Sciences, 6(2), 2014, 66-69. 